\title{
Geostatistical models for land capability evaluation of Wadi Tag El-Wabar, Sohag, Egypt
}

\author{
El-Sayed M. A. ${ }^{a^{*}}$, Faragallah M. A. ${ }^{\text {a }}$, El-Desoky A. I. ${ }^{a}$, Fadl M. E. ${ }^{\text {b }}$ \\ ${ }^{a}$ Department of Soils and Water, Faculty of Agriculture, Al-Azhar University, Assiut, Egypt \\ ${ }^{b}$ Division of Scientific Training and Continuous Studies, National Authority for Remote Sensing and Space \\ Sciences (NARSS), Cairo, Egypt
}

\begin{abstract}
This study aims to evaluate the land capability and assess geostatistical models for some soils of Wadi Tag ElWabar located at south-western of Sohag governorate, Egypt. The investigated area is a part of the western desert; it is lies between latitudes $26^{\circ} 3^{\prime} 50^{\prime \prime}$ to $26^{\circ} 18^{\prime} 00^{\prime \prime} \mathrm{N}$ and longitudes $31^{\circ} 33^{\prime} 00^{\prime \prime}$ to $31^{\circ} 45^{\prime} 00^{\prime \prime} \mathrm{E}$. According to geomorphological units and recent digital image, thirty soil profiles were chosen to represent the studied area. The obtained results indicated that Wadi Tag El-Wabar soils are included four capability classes i.e. Grade 2 (Good), Grade 3 (Fair), Grade 4 (Poor) and Grade 5 (Non-agricultural) that represents 4.13, 30.07, 34.92 and $30.88 \%$, respectively, of total area, by applying modified Storie rating. Geostatistical analysis for land capability rates were calculated through variance structure using eight semivariogram models (Circular, Pentaspherical, Exponential, Gaussian, Rational Quadratic, Hole Effect, K-Bessel and J-Bessel). All geostatistical models were fitted to the experimental semivariogram analysis using two kriged types (Kriging and Co-Kriging). These models were evaluated by five prediction errors i.e. mean, root mean square, average standard error, mean standardized and root mean square standardized. The results showed that Hole Effect and J-Bessel models were the best used models. A positive correlation $\left(\mathrm{r}^{2}=0.7933\right)$ was recorded between the Hole Effect and J-Bessel semivariogram models.
\end{abstract}

Keywords: geostatistical analysis, land capability, modeling, Wadi Tag El-Wabar.

*Corresponding author: El-Sayed M. A., 


\section{Introduction}

Land evaluation plays an important role in the development of agriculture sustainable. It provides information about the opportunities and constraints for land use as a basis for making decisions on its use and management (FAO, 1983). Land capability evaluation refers to a range of major kinds of land uses, such as agriculture, forestry, livestock production, and recreation (Sys et al., 1991). Capability classes are groups of land units that have the same degree of limitations and the risks of soil damage which varied from class I (best) to VIII (worst) (Rossiter, 2001). Also, land capability is a qualitative methodology in order to classify land resources based on soil, topography and climate parameters without taking into account the yield and socio-economic conditions (Abuzaid and Fadl, 2016). The Storie index is a semiquantitative method of rating soils used mainly for irrigated agriculture based on crop productivity data collected from major soils. It assesses the productivity of a soil from the following four characteristics: Factor A represent the degree of soil profile development, factor $\mathrm{B}$ is surface texture, factor $\mathrm{C}$ is represented by slope, and factor $\mathrm{x}$ was considered other soils and landscape conditions including the sub-factors drainage, fertility, acidity, erosion, and microelief. A score ranging from 0 to 100 determined for each factor then multiplied together to generate an index rating according to O'Geen et al. (2008). Geostatistical mapping and techniques that including analyses of semivariogram $\gamma(\mathrm{h})$, cross-validation, kriging and spatial distribution mapping of kriged estimates; are used to determine the variance structure of soil characteristics. Geographic information system and remote sensing systems have been used for soil mapping successfully in different areas and considered a useful appliance tools for devices to processing large amounts of spatial data of land resources (Abuzaid and Fadl, 2018; Goovaerts, 1999). Geostatistical methods and remote sensing data correlations have been become increasingly popular using due to its have employing available information for spatial resolution of the variable sampled target, generally, it generate more accurate results than those of the univariate methods when the correlation between primary and secondary variables is significant (Goovaerts, 1997). Soils are one of the most precious natural resources and the basic soil resource information is a prerequisite for planning sustainable agriculture (Awad, 2018). These informations are necessary to optimizing land use and developmental activities especially in arid regions like Egypt (FAO and ITPS, 2015; Singh et al., 2017). Therefore, locating new areas having agricultural potential is a highly priority task for the government to narrow the gap between food consumption and its production. South western desert is considered as one of the promising regions that have the potentialities to share in producing food and life requirements (Ismail et al., 2010). Wadi Tag El-Wabar is located at the southwestern part of Sohag governorate, Egypt. It's considered as one of the promising area for agricultural expansion with total area 76713.6 feddans (feddan $=0.420$ 
hectares $=1.037$ acres) that has not been studied previously and most of it is characterized by wide semi-flat areas. The present study aims to evaluate the land capability and assess geostatistical models for some soils of Wadi Tag El-Wabar, Sohag, Egypt in order to assist the decision maker to improve and achievement the agriculture sustainable developments.

\section{Materials and methods}

Wadi Tag El-Wabar is a part of the western desert which located at the south-western of Sohag governorate, Egypt between latitudes $26^{\circ} 3^{\prime} 50^{\prime \prime}$ to $26^{\circ} 18^{\prime} 00^{\prime \prime} \mathrm{N}$ and longitudes $31^{\circ} 33^{\prime} 00^{\prime \prime}$ to $31^{\circ} 45^{\prime} 00^{\prime \prime}$ E (Figure 1). Generally, Sohag governorate that characterized by hot summers and cold winters with a clear change in temperature, a rarity in rain and relatively high moisture content.
Based on the available geomorphologic units, thirty soil profiles representing the study area were selected. Locations of these soil profiles were recorded in the field using the Global Positioning System "Garmin GPS" and plotted on the map (Figure 2). It was dug up to the suitable depth according to soil material nature and their morphological characteristics were described according to FAO (2006) and Schoenberger et al. (2012). Soil samples were collected from different layers of all investigated soil profiles, according to the morphological variation. The collected soil samples were air-dried, crushed, sieved to pass through $2 \mathrm{~mm}$ sieve and stored in plastic containers for different analysis. Particle size distribution was performed on the studied soil samples according to Gavlak et al. (2005). The gravel content was measured volumetric according to Schoenberger $e t$ al. (2012).

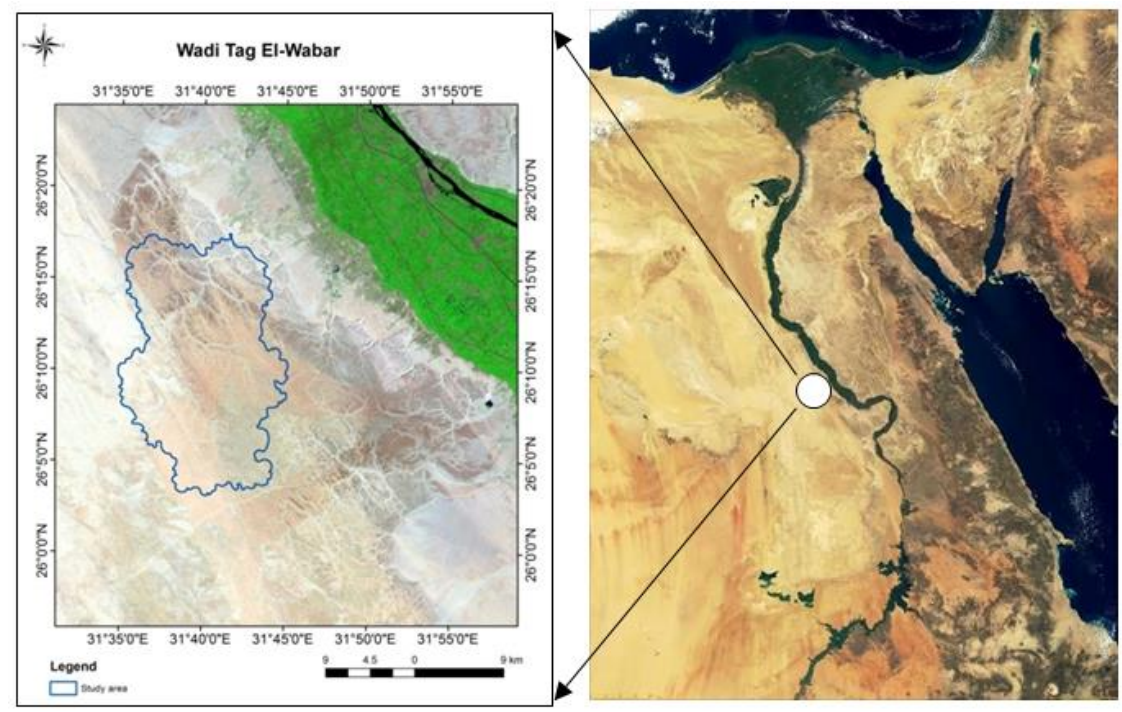

Figure (1): The studied area location map. 


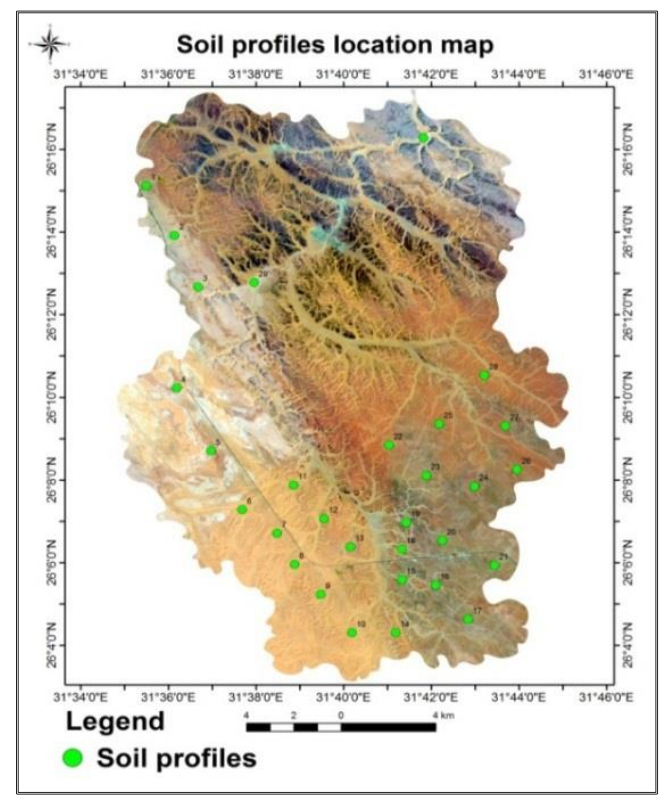

Figure (2): Soil profile locations map

According to Burrough and McDonell (1998) slope percent was calculated and extracted from digital elevation model (DEM) using remote sensing and GIS techniques from each cell of the raster data surface as a percentage through the following equation:

$$
\text { Percent of slope }=\frac{\text { rise }}{\text { run }} \times 100
$$

Saturation percentage (SP) was measured as described by Hesse (1998). The soil organic matter (SOM) was estimated using Walkley-Black method (Bashour and Sayegh, 2007). Soil reaction $(\mathrm{pH})$ was measured in 1: 2.5 of soil to water suspension at $25{ }^{\circ} \mathrm{C}$ using a glass electrode (Alvarenga et al., 2012). Total calcium carbonates $\left(\mathrm{CaCO}_{3}\right)$ were determined using a calibrated Scheibler's calcimeter (Nelson, 1982). Soil salinity $\left(\mathrm{EC}_{\mathrm{e}}\right)$ in the saturated soil paste extract was measured using a Beckman Conductivity Bridage at $25{ }^{\circ} \mathrm{C}$ according to Bashour and Sayegh (2007). Gypsum was determined using the precipitation with acetone according to Nelson (1982). Sodium adsorption ratio $\left(\mathrm{SAR}_{\mathrm{e}}\right)$ of saturated soil past extract was calculated using this equation that described by (Richards, 1954).

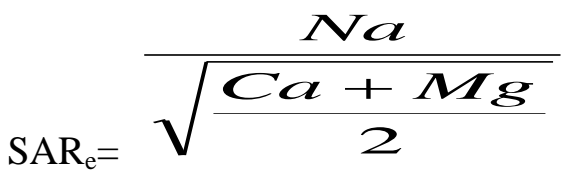

The cation exchangeable capacity (CEC) was measured using $1 \mathrm{M}$ sodium acetate (NaOAc) solution ( $\mathrm{pH}$ 8.2) as a saturation solution and then, exchangeable $\left(\mathrm{Na}^{+}\right)$was replaced by 
$\mathrm{NH}_{4}{ }^{+}$using $1 \mathrm{M}$ ammonium acetate $\left(\mathrm{NH}_{4} \mathrm{OAc}\right.$ ) solution ( $\mathrm{pH}$ 7.0) (Bashour and Sayegh, 2007). The replaced $\left(\mathrm{Na}^{+}\right)$ ions were estimated using flame photometer. Exchangeable sodium percentage (ESP) was determined using ammonium acetate method (Bashour and Sayegh, 2007) and calculated using the values of CEC and exchangeable sodium by the following equation:

$$
\mathrm{ESP}=\frac{\mathrm{Na}+(\operatorname{coml}(+) / \mathrm{kg}-1)}{\operatorname{CEC}(\operatorname{coml}(+) / \mathrm{kg}-1)} \times 100
$$

Modified Storie index rating (O'Geen et al., 2008) is widely and acceptable soil evaluation method using for land use and capability of arid and semi-arid regions . The calculation was run and coding using Visual Basic for application under Microsoft Excel, according to Aldbaa (2012) based on the following equation:

Storie Index $=[(\mathrm{A} / 100) \times(\mathrm{B} / 100) \times(\mathrm{C} / 100) \times$ $(\mathrm{X} / 100)] \times 100$

Where: $\mathrm{A}=$ soil profile depth $(\mathrm{cm}), \mathrm{B}=$ Soil texture, $\mathrm{C}=$ Slope and $\mathrm{X}=$ Other soil factors includes; topographic, drainage, fertility, nutrient level, erosion, microrelief and alkalinity, as shown in Table (1).

Table (1): Land capability classes, soil grades and productivity rating using the modified storie index (O'Geen et al., 2008).

\begin{tabular}{|l|l|l|l|l|}
\hline Soil factors & Soil properties & Capability classes & Grade & Productivity rating (\%) \\
\hline A & Physical properties & Excellent & Grade 1 & $80-100$ \\
\hline B & Soil Texture & Good & Grade 2 & $60-79$ \\
\hline C & Slope & Fair & Grade 3 & $40-59$ \\
\hline \multirow{2}{*}{ X } & \multirow{2}{*}{ Other soil factors } & Poor & Grade 4 & $20-39$ \\
\cline { 3 - 5 } & & Non agricultural & Grade 5 & $<20$ \\
\hline
\end{tabular}

Landsat 8 Enhanced Thematic Mapper $(\mathrm{ETM}+)$ satellite image was used as the source data for the investigated study to identify different maps of the study area using ENVI 5.1 software (ITT, 2017). Land capability and geostatistics modeling maps were produced using ArcGIS 10.2.2 software (ESRI, 2014). Geostatistics is a class of statistics used to analyze and predict the values associated with spatial or spatiotemporal phenomena. It incorporates the spatial (and in some cases temporal) coordinates of the data within the analyses (ESRI,
2014). Geostatistical mapping and techniques including analyses of Semivariogram $\gamma(\mathrm{h})$, cross-validation, kriging and spatial distribution mapping of kriged estimates were used to determine the variance structure for land capability. Geostatistical analysis in the study was performed using the geostatistical analyst extension of ArcGIS 10.2.2 (ESRI, 2014). The experimental semi-variogram is a graphical representation of the mean square variability between two neighboring points of distance $h$ as shown in equation: 


$$
\gamma(h)=\frac{1}{2 N(h)} \sum_{i=1}^{N(h)}[Z(x i+h)-Z(x i)]^{2}
$$

Where: $\quad \gamma(\mathrm{h})$ is the semi-variogram expressed as a function of the magnitude of the lag distance or separation vector $h$, $\mathrm{N}(\mathrm{h})$ is the number of observation pairs separated by distance $\mathrm{h}$ and $\mathrm{z}\left(\mathrm{x}_{\mathrm{i}}\right)$ is the random variable at location $\mathrm{x}_{\mathrm{i}}$.

\section{Results and Discussion}

\section{1 Soil properties of the study area}

The profile weighted mean values of some soil properties of the studied area are represented in Table (2). The results showed that these soils have a texture ranging from medium-texture (loam), moderately coarse-texture (sandy loam), coarse-texture (loamy sand), gravelly loamy sand, very gravelly loam, gravelly sandy loam, very gravelly sandy loam and extremely gravelly sandy loam. In all study area, gravel content ranges from 0.59 to $70.04 \%$. Area is flat or almost flat (slope present is between 0.23 to $4.6 \%$ ) with profile depth ranged between 50 and $150 \mathrm{~cm}$. The saturation percentage (SP\%) of these soils varies between $20.88 \%$ and $40.05 \%$. Low soil organic matter content $(0.12-0.44 \%)$ that referring to the prevailing arid climate and barren nature of the region.

Table (2): Profiles weighted mean of some soil characteristics of the studied area.

\begin{tabular}{|c|c|c|c|c|c|c|c|c|c|c|c|c|c|}
\hline $\begin{array}{c}\text { Profile } \\
\text { No. }\end{array}$ & $\begin{array}{c}\text { Depth } \\
(\mathrm{cm})\end{array}$ & $\begin{array}{c}\text { Texture } \\
\text { grade }\end{array}$ & $\begin{array}{c}\text { Gravel by } \\
\text { volume }(\%)\end{array}$ & $\begin{array}{c}\text { Slope } \\
(\%)\end{array}$ & $\begin{array}{l}\text { SP } \\
(\%)\end{array}$ & $\begin{array}{l}\mathrm{OM} \\
(\%)\end{array}$ & $\begin{array}{c}\mathrm{CaCO}_{3} \\
(\%) \\
\end{array}$ & $\begin{array}{c}\text { Gypsum } \\
(\%)\end{array}$ & $\begin{array}{c}\mathrm{pH} \\
(1: 2.5)\end{array}$ & $\begin{array}{c}\mathrm{EC}_{\mathrm{e}} \\
(\mathrm{dS} / \mathrm{m}) \\
\end{array}$ & $\mathrm{SAR}_{\mathrm{e}}$ & $\begin{array}{l}\text { ESP } \\
(\%)\end{array}$ & $\begin{array}{c}\mathrm{CEC} \\
(\mathrm{Cmol}(+) / \mathrm{Kg})\end{array}$ \\
\hline 1 & 150 & SL & 0.59 & 1.2 & 31.6 & 0.44 & 40.78 & 1.3 & 8.65 & 21.44 & 12.28 & 9.62 & 7.42 \\
\hline 2 & 100 & VGL & 44.84 & 1.2 & 30.2 & 0.32 & 60.53 & 0.95 & 8.9 & 13.56 & 9.79 & 8.36 & 10.32 \\
\hline 3 & 120 & GSL & 27.28 & 3.3 & 26.5 & 0.26 & 56.76 & 0.93 & 8.68 & 17.17 & 10.53 & 7.48 & 5.46 \\
\hline 4 & 50 & SL & 5.23 & 0.3 & 26.8 & 0.34 & 63.36 & 0.28 & 8.79 & 10.28 & 9.51 & 9.78 & 6.06 \\
\hline 5 & 55 & SL & 8.8 & 2.1 & 24.8 & 0.3 & 47.99 & 2.36 & 8.43 & 42.89 & 19.68 & 14.01 & 11.41 \\
\hline 6 & 150 & LS & 10.78 & 2.1 & 22.3 & 0.17 & 4.32 & 0.08 & 8.15 & 2.35 & 3.99 & 4.48 & 2.8 \\
\hline 7 & 150 & EGSL & 67.4 & 0.7 & 25.3 & 0.17 & 15.83 & 0.83 & 7.75 & 13.85 & 13.19 & 13.8 & 5.9 \\
\hline 8 & 150 & EGSL & 70.04 & 0.8 & 40.1 & 0.16 & 10.61 & 2.05 & 7.9 & 31.29 & 10.98 & 8.42 & 9.56 \\
\hline 9 & 150 & GSL & 29.47 & 3.4 & 35.6 & 0.18 & 9.92 & 2.22 & 7.59 & 51.03 & 18.17 & 13.11 & 7.25 \\
\hline 10 & 110 & SL & 10.51 & 3.1 & 25.1 & 0.14 & 62.35 & 0.59 & 7.95 & 4.12 & 7.99 & 5.88 & 6.04 \\
\hline 11 & 150 & EGSL & 62.64 & 1.4 & 32.9 & 0.24 & 14.69 & 1.7 & 7.8 & 35.87 & 18.87 & 12.81 & 5.85 \\
\hline 12 & 150 & SL & 1.02 & 1.2 & 30.2 & 0.27 & 42.8 & 1.02 & 7.87 & 25.43 & 12.48 & 9.28 & 12.31 \\
\hline 13 & 150 & GSL & 17.23 & 0.4 & 27.5 & 0.23 & 40.74 & 0.18 & 8.26 & 3.61 & 5.02 & 4.06 & 8.04 \\
\hline 14 & 150 & GSL & 25.14 & 4.6 & 27.2 & 0.25 & 40.31 & 1.79 & 7.74 & 59.19 & 18.69 & 15.18 & 6.81 \\
\hline 15 & 110 & GLS & 26.08 & 1 & 20.9 & 0.12 & 14.3 & 0.03 & 8.09 & 0.97 & 1.58 & 2.05 & 4.23 \\
\hline 16 & 110 & $\mathrm{~L}$ & 8.59 & 1.3 & 28.8 & 0.12 & 58.55 & 0.04 & 7.96 & 0.83 & 2.09 & 2.33 & 10.63 \\
\hline 17 & 120 & GLS & 29.8 & 1.6 & 20.9 & 0.22 & 16.75 & 0.46 & 8.11 & 6.03 & 6.39 & 5.98 & 2.9 \\
\hline 18 & 150 & SL & 11.32 & 0.6 & 24.9 & 0.17 & 30.72 & 0.17 & 8.24 & 0.47 & 1.7 & 1.48 & 7.69 \\
\hline 19 & 110 & SL & 5.02 & 1.8 & 26.3 & 0.35 & 34.58 & 2.56 & 7.54 & 105.76 & 28 & 16.91 & 9.04 \\
\hline 20 & 150 & $\mathrm{SL}$ & 14.36 & 0.9 & 27.4 & 0.37 & 24.94 & 2.42 & 7.59 & 84.78 & 20.95 & 10.62 & 8.89 \\
\hline 21 & 150 & GSL & 20.05 & 0.7 & 28.9 & 0.14 & 21.16 & 1.12 & 7.67 & 31.59 & 16.15 & 11 & 5.92 \\
\hline 22 & 130 & GSL & 27.76 & 1.3 & 24.2 & 0.31 & 26.46 & 2.27 & 7.65 & 80.22 & 21.52 & 18.02 & 8.55 \\
\hline 23 & 110 & VGSL & 40.63 & 1 & 25 & 0.33 & 17.38 & 3.12 & 7.76 & 105.95 & 32.19 & 18.82 & 9.37 \\
\hline 24 & 150 & $\mathrm{~L}$ & 0.62 & 1.5 & 27.5 & 0.28 & 51.06 & 2.63 & 7.69 & 41.01 & 17.83 & 15.13 & 10.06 \\
\hline 25 & 120 & LS & 7.28 & 1.2 & 23.1 & 0.18 & 25.49 & 0.07 & 8.43 & 1.46 & 2.39 & 2.35 & 5.11 \\
\hline 26 & 150 & SL & 0.64 & 0.6 & 24.8 & 0.2 & 17.59 & 0.07 & 8.4 & 13.11 & 10.11 & 7.39 & 6 \\
\hline 27 & 150 & SL & 4.86 & 1.8 & 28.4 & 0.33 & 56.43 & 2.81 & 7.8 & 50.37 & 15.21 & 11.57 & 9.34 \\
\hline 28 & 150 & GSL & 22.82 & 1 & 25.2 & 0.37 & 47.56 & 5.36 & 7.68 & 103.69 & 23.55 & 20 & 7.41 \\
\hline 29 & 120 & LS & 7.6 & 0.9 & 21.9 & 0.26 & 15.7 & 0.09 & 8.38 & 1.35 & 1.68 & 2.51 & 4.01 \\
\hline 30 & 150 & SL & 7.6 & 3.3 & 25.3 & 0.13 & 11.89 & 0.38 & 8 & 2.47 & 1.97 & 1.52 & 5.77 \\
\hline
\end{tabular}

Total calcium carbonate $\left(\mathrm{CaCO}_{3}\right)$ of these area varies from moderately calcareous
$(4.32 \%)$ to extremely calcareous $(63.36 \%)$, the highest amounts of $\mathrm{CaCO}_{3}$ 
reflecting the calcareous parent material nature of these soils. The results also reveal that the gypsum content values vary between $0.03 \%$ and $5.36 \%$ that indicating slightly gypsiric to moderately gypsiric soils (FAO, 2006). According to Schoenberger et al. (2012), slightly (7.54) to strongly (8.9) alkaline soil reaction of the investigated soil. The $\mathrm{EC}_{\mathrm{e}}$ values of the studied area vary between non-saline (0.47) to strongly saline $\left(105.95 \mathrm{dSm}^{-1}\right)$ (Schoenberger et al., 2012). The high amount of salts may be referring to a lack of rainfall consequently less leaching and /or due to the nature of the soil parent material. The values of sodium adsorption ratio $\left(\mathrm{SAR}_{\mathrm{e}}\right)$ ranged from 1.58 and 32.19. The high $\mathrm{SAR}_{\mathrm{e}}$ values seemed to be associated with the high $\mathrm{EC}_{\mathrm{e}}$ values. Most soil profiles revered low $\mathrm{SAR}_{\mathrm{e}}$ values less than 13 indicate a low sodicity hazard (FAO, 2006). Exchangeable sodium percentage (ESP) of these soils ranges from 1.48 and $20 \%$. Some soils which represented by soil profiles $14,19,22,23$, 24 , and 28 are sodic soils (> 15\%). Also, the observed cation exchange capacity (CEC) was low that ranged from 2.80 to $12.31 \mathrm{cmol}(+) / \mathrm{kg}$ which associated with coarse-textured soils (loamy sand), whereas the highest values were found in medium texture (loam).

\subsection{Land evaluation of the study area}

\subsubsection{Modified Storie Index (2008)}

According to the Modified Storie index O'Geen et al. (2008), the studied area has grades 2, 3, 4 and 5 capability classes due to different limiting factors (Tables 3, 4 and 5 and Figure 3). The limiting factors include salinity and sodium adsorption ratio $\left(\mathrm{SAR}_{\mathrm{e}}\right)$ that can be adjustable while, soil depth, slope, gravel, and soil texture factors are difficultly amendable. Therefore, the investigated area could be classified into the following grades: Grade 2 (Good) that was represented by soil profiles 16, 18 and 30 with about $4.13 \%$ of the total area.

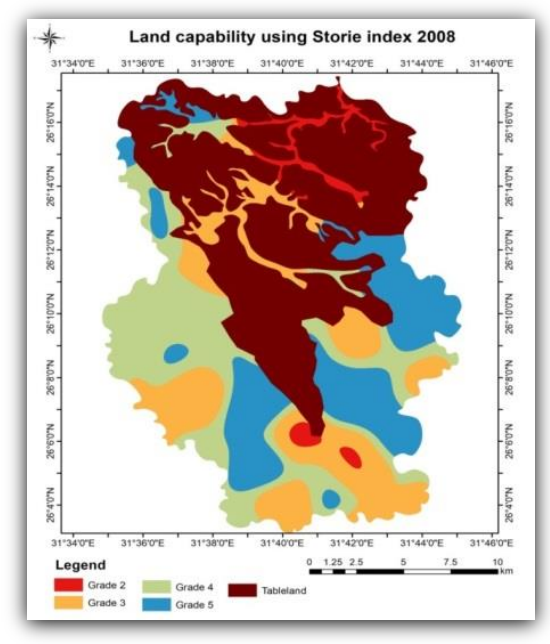

Figure (3): Land capability classification of the study area. 
Table (3): Land capability classification of the study area using the modified storie index.

\begin{tabular}{|c|c|c|c|c|c|}
\hline No. & Capability grade & Capability classes & Area $/ \mathrm{km}^{2}$ & Area/Fadden & Area (\%) \\
\hline 1 & Grade 2 & Good & 7.85 & 1868.68 & 4.13 \\
\hline 2 & Grade 3 & Fair & 57.20 & 13618.02 & 30.07 \\
\hline 3 & Grade 4 & Poor & 66.40 & 15810.13 & 34.92 \\
\hline 4 & Grade 5 & Non agricultural & 58.71 & 13978.93 & 30.88 \\
\hline \multicolumn{2}{|c|}{ Total } & 190.16 & 45275.75 & 100 \\
\hline
\end{tabular}

Table (4): Land capability classes and soil limitations of the studied area according to O'Geen et al. (2008).

\begin{tabular}{|c|c|c|c|c|c|c|c|}
\hline \multirow{2}{*}{$\begin{array}{l}\text { Capability } \\
\text { index (Ci \%) }\end{array}$} & \multirow{2}{*}{ Grade } & \multirow{2}{*}{$\begin{array}{c}\text { Capability } \\
\text { class }\end{array}$} & \multirow[b]{2}{*}{ Soil limitation } & \multirow{2}{*}{ Profile No. } & \multicolumn{3}{|c|}{ Area } \\
\hline & & & & & $\left(\mathrm{km}^{2}\right)$ & (Hectare) & $(\%)$ \\
\hline \multirow{2}{*}{$60-79$} & \multirow{2}{*}{ Grade 2} & \multirow{2}{*}{ Good } & ....... & 16 & \multirow{2}{*}{7.85} & \multirow{2}{*}{784.84} & \multirow{2}{*}{4.13} \\
\hline & & & Gravel and $\mathrm{EC}_{\mathrm{e}}$ & 30 & & & \\
\hline \multirow{3}{*}{$40-59$} & \multirow{3}{*}{ Grade 3} & \multirow{3}{*}{ Fair } & Gravel , $\mathrm{SAR}_{\mathrm{e}}, \mathrm{EC}_{\mathrm{e}}$ and texture & 6 & \multirow{3}{*}{57.20} & \multirow{3}{*}{5719.57} & \multirow{3}{*}{30.07} \\
\hline & & & Gravel and texture & 15 & & & \\
\hline & & & Gravel, $\mathrm{EC}_{\mathrm{e}}$ and texture & 25 and 29 & & & \\
\hline \multirow{3}{*}{$20-39$} & \multirow{3}{*}{ Grade 4} & \multirow{3}{*}{ Poor } & Depth, $\mathrm{SAR}_{\mathrm{e}}$ and $\mathrm{EC}_{\mathrm{e}}$, & 4 & \multirow{3}{*}{66.40} & \multirow{3}{*}{6640.25} & \multirow{3}{*}{34.92} \\
\hline & & & $\mathrm{SAR}_{\mathrm{e}}$ and $\mathrm{EC}_{\mathrm{e}}$ & 26 & & & \\
\hline & & & Gravel, $\mathrm{SAR}_{\mathrm{e}}, \mathrm{EC}_{\mathrm{e}}$ and texture & 17 & & & \\
\hline$<20$ & Grade 5 & $\begin{array}{c}\text { Non } \\
\text { agricultural }\end{array}$ & $\mathrm{SAR}_{\mathrm{e}}$ and $\mathrm{EC}_{\mathrm{e}}$ & $1,12,19,24$ and 27 & 58.71 & 5871.15 & 30.88 \\
\hline
\end{tabular}

These soils are deep, moderately coarse textured (sandy loam), medium textured (loam) and suitable for most crops. Grade 3 (Fair) which was described by soil profiles $6,10,13,15,25$ and $29,30.07 \%$ of the total studied area with deep profile, coarse-textured (loamy sand), moderately coarse textured (sandy loam), and less wide range of suitability for crops than grade 2. Grade 4 (Poor) was represented by soil profiles 4,17 and 26 by about $34.92 \%$ of the total investigated area. These soils are vary from shallow to deep, coarse-textured (loamy sand), moderately coarse textured (sandy loam), and have moderate limitations that show somewhat suitable limited crops or poor for agricultural use. Grade 5 (Nonagricultural) that was delineated by soil profiles of $1,2,3,5,7,8,9,11,12,14$, $19,20,21,22,23,24,27$ and 28 , by about
$30.88 \%$ of the total area. These soils are moderately deep to deep, moderately coarse textured (sandy loam), medium textured (loam) and have moderate to strong limitations which show unsuitable for crops. Similar results are also obtained by Faragllah (2001), El-Sayed (2016) and Sayed et al., (2016).

\subsection{Geostatistical analysis}

Geostatistical analysis for land capability rates were calculated using variance structure that was performed using eight semivariogram models (Circular, Pentaspherical, Exponential, Gaussian, Rational Quadratic, Hole Effect, K-Bessel and J-Bessel) and mapping land capability distribution. Five indices were used to evaluate all models, (Goovaerts, 1997): Mean prediction errors (MPE), root mean 
square prediction errors (RMSPE), that must be close to 0 and root mean average standard error (ASE), mean square standardized prediction errors standardized prediction errors (MSPE) (RMSSPE) that must close to 1.

Table (5): Land capability and modified Storie index rating of the studied area according to O'Geen et al. (2008).

\begin{tabular}{|c|c|c|c|c|c|c|c|c|c|}
\hline Profile No & Depth & Gravel & Slope & $\mathrm{pH}$ & $\mathrm{SAR}_{\mathrm{e}}$ & $\mathrm{EC}_{\mathrm{e}}$ & Texture & Index & Capability classes \\
\hline 1 & 97.3 & 99.4 & 98.6 & 100.0 & 81.8 & 24.9 & 95.0 & 17.68 & Non agricultural \\
\hline 2 & 93.0 & 62.4 & 98.6 & 100.0 & 85.3 & 50.1 & 100.0 & 19.79 & Non agricultural \\
\hline 3 & 95.0 & 76.1 & 96.2 & 100.0 & 84.2 & 38.2 & 95.0 & 18.80 & Non agricultural \\
\hline 4 & 47.8 & 95.2 & 99.7 & 100.0 & 85.7 & 61.5 & 95.0 & 20.91 & Poor \\
\hline 5 & 53.1 & 91.9 & 97.6 & 100.0 & 72.5 & 30.2 & 95.0 & 18.18 & Non agricultural \\
\hline 6 & 97.3 & 90.2 & 97.6 & 100.0 & 93.7 & 90.8 & 80.0 & 55.88 & Fair \\
\hline 7 & 97.3 & 46.9 & 99.2 & 100.0 & 80.6 & 49.2 & 95.0 & 16.33 & Non agricultural \\
\hline 8 & 97.3 & 45.2 & 99.1 & 100.0 & 83.6 & 2.9 & 95.0 & 15.52 & Non agricultural \\
\hline 9 & 97.3 & 74.3 & 96.1 & 100.0 & 74.3 & 45.8 & 95.0 & 9.22 & Non agricultural \\
\hline 10 & 93.9 & 90.4 & 96.4 & 100.0 & 87.8 & 84.0 & 95.0 & 48.79 & Fair \\
\hline 11 & 97.3 & 50.0 & 98.4 & 100.0 & 73.4 & 14.4 & 95.0 & 14.60 & Non agricultural \\
\hline 12 & 97.3 & 99.0 & 98.6 & 100.0 & 81.6 & 13.1 & 95.0 & 9.24 & Non agricultural \\
\hline 13 & 97.3 & 84.5 & 99.5 & 100.0 & 92.2 & 85.9 & 95.0 & 59.07 & Fair \\
\hline 14 & 97.3 & 77.8 & 94.7 & 100.0 & 73.7 & 58.5 & 95.0 & 18.12 & Non agricultural \\
\hline 15 & 93.9 & 77.1 & 98.8 & 100.0 & 97.5 & 96.2 & 80.0 & 45.63 & Fair \\
\hline 16 & 93.9 & 92.1 & 98.5 & 100.0 & 96.7 & 96.7 & 100.0 & 67.75 & Good \\
\hline 17 & 95.0 & 74.0 & 98.2 & 100.0 & 90.1 & 76.8 & 80.0 & 33.83 & Poor \\
\hline 18 & 97.3 & 89.7 & 99.3 & 100.0 & 97.3 & 98.1 & 95.0 & 75.37 & Good \\
\hline 19 & 93.9 & 95.4 & 97.9 & 100.0 & 63.4 & 75.4 & 95.0 & 13.25 & Non agricultural \\
\hline 20 & 97.3 & 87.0 & 99.0 & 100.0 & 71.0 & 79.6 & 95.0 & 16.44 & Non agricultural \\
\hline 21 & 97.3 & 82.1 & 99.2 & 100.0 & 76.8 & 3.7 & 95.0 & 12.57 & Non agricultural \\
\hline 22 & 95.6 & 75.7 & 98.5 & 100.0 & 70.3 & 77.9 & 95.0 & 17.21 & Non agricultural \\
\hline 23 & 93.9 & 65.6 & 98.8 & 100.0 & 59.3 & 75.3 & 95.0 & 14.33 & Non agricultural \\
\hline 24 & 97.3 & 99.4 & 98.3 & 100.0 & 74.7 & 26.2 & 100.0 & 16.77 & Non agricultural \\
\hline 25 & 95.0 & 93.3 & 98.6 & 100.0 & 96.2 & 94.2 & 80.0 & 56.06 & Fair \\
\hline 26 & 97.3 & 99.4 & 99.3 & 100.0 & 84.8 & 51.7 & 95.0 & 38.33 & Poor \\
\hline 27 & 97.3 & 95.5 & 97.9 & 100.0 & 78.0 & 44.6 & 95.0 & 11.21 & Non agricultural \\
\hline 28 & 97.3 & 79.8 & 98.8 & 100.0 & 68.0 & 76.7 & 95.0 & 10.24 & Non agricultural \\
\hline 29 & 95.0 & 93.0 & 99.0 & 100.0 & 97.3 & 94.7 & 80.0 & 56.99 & \begin{tabular}{|l} 
Fair \\
\end{tabular} \\
\hline 30 & 97.3 & 93.0 & 96.2 & 100.0 & 96.9 & 90.3 & 95.0 & 69.39 & Good \\
\hline
\end{tabular}

Table (6): Fitted parameters of the variogram model for land capability distribution.

\begin{tabular}{|c|c|c|c|c|c|c|c|c|c|}
\hline \multirow[b]{2}{*}{ Parameters } & \multirow[b]{2}{*}{ Models } & \multicolumn{8}{|c|}{ Prediction Errors } \\
\hline & & Mean & $\begin{array}{c}\text { Root } \\
\text { Mean } \\
\text { Square }\end{array}$ & $\begin{array}{c}\text { Average } \\
\text { Standard } \\
\text { Error }\end{array}$ & $\begin{array}{c}\text { Mean } \\
\text { Standardized }\end{array}$ & $\begin{array}{l}\text { Root Mean } \\
\text { Square } \\
\text { Standardized }\end{array}$ & Skewness & Kurtosis & Std. Dv \\
\hline \multirow{8}{*}{$\begin{array}{c}\text { Land } \\
\text { capability } \\
\text { classification } \\
\text { using modified } \\
\text { storie index } \\
2008\end{array}$} & Circular & -0.10 & 22.26 & 20.14 & -0.33 & 1.66 & \multirow{8}{*}{0.37} & \multirow{8}{*}{1.70} & \multirow{8}{*}{0.65} \\
\hline & Pentaspherical & 0.03 & 21.30 & 23.67 & -0.19 & 1.20 & & & \\
\hline & \begin{tabular}{|l} 
Exponential \\
\end{tabular} & -0.24 & 21.15 & 23.07 & $\begin{array}{ll}-0.18 \\
\end{array}$ & 1.19 & & & \\
\hline & \begin{tabular}{|l|} 
Gaussian \\
\end{tabular} & 0.12 & 23.26 & 17.98 & -0.47 & 1.13 & & & \\
\hline & \begin{tabular}{|c|} 
Rational \\
Quadratic
\end{tabular} & -0.12 & 21.06 & 23.93 & -0.16 & 1.13 & & & \\
\hline & Hole Effect & 1.08 & 21.22 & 26.88 & -0.12 & 1.04 & & & \\
\hline & \begin{tabular}{|l} 
K-Bessel \\
\end{tabular} & 0.02 & 20.95 & 25.65 & -0.12 & 1.00 & & & \\
\hline & J-Bessel & 1.01 & 21.27 & 26.58 & -0.27 & 1.05 & & & \\
\hline
\end{tabular}




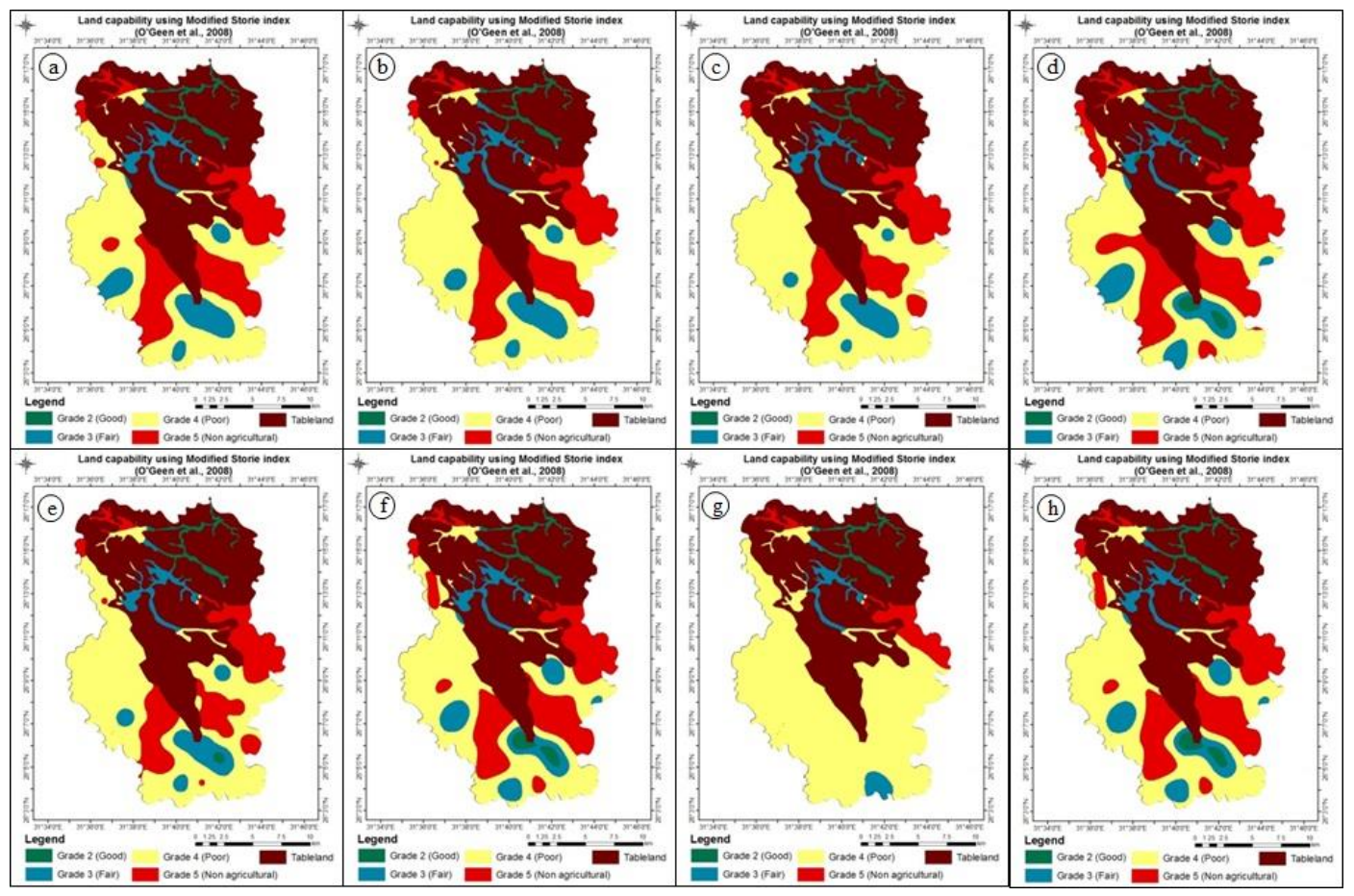

Figure (4): Modified storie index for land capability distribution using semivariograms Circular (a), Pentaspherical (b), Exponential (c), Gaussian (d), Rational Quadratic (e), Hole Effect (f), K-Bessel (g) and JBessel (h) models.

Data in Table (6) and Figure (4) indicate that the best semivariogram models were Hole Effect and J-Bessel based on their values. Mean prediction errors (MPE) values were 1.08 and 1.01 with Hole Effect and J-Bessel semivariogram models respectively, meanwhile the values of root mean square prediction errors (RMSPE) and average standard error (ASE) refer to it is enough to be closed to each others for all models. On the other hand, mean standardized prediction errors (MSPE) values were closed to 0 with Hole Effect and J-Bessel based models (-0.12 and -0.27$)$ and root mean square standardized prediction errors (RMSSPE) was closed to 1 with Hole Effect and J-Bessel models (1.04 and 1.05).

\subsection{Linear regression analysis correlating}

Linear regression analysis correlating was used to represent the relationship between the best semivariogram models (Hole Effect and J-Bessel) and the spatial land capability distribution mapping. A positive correlation $\left(r^{2}=0.7933\right)$ was calculated between the Hole Effect and JBessel semivariogram models (Figure 5). 


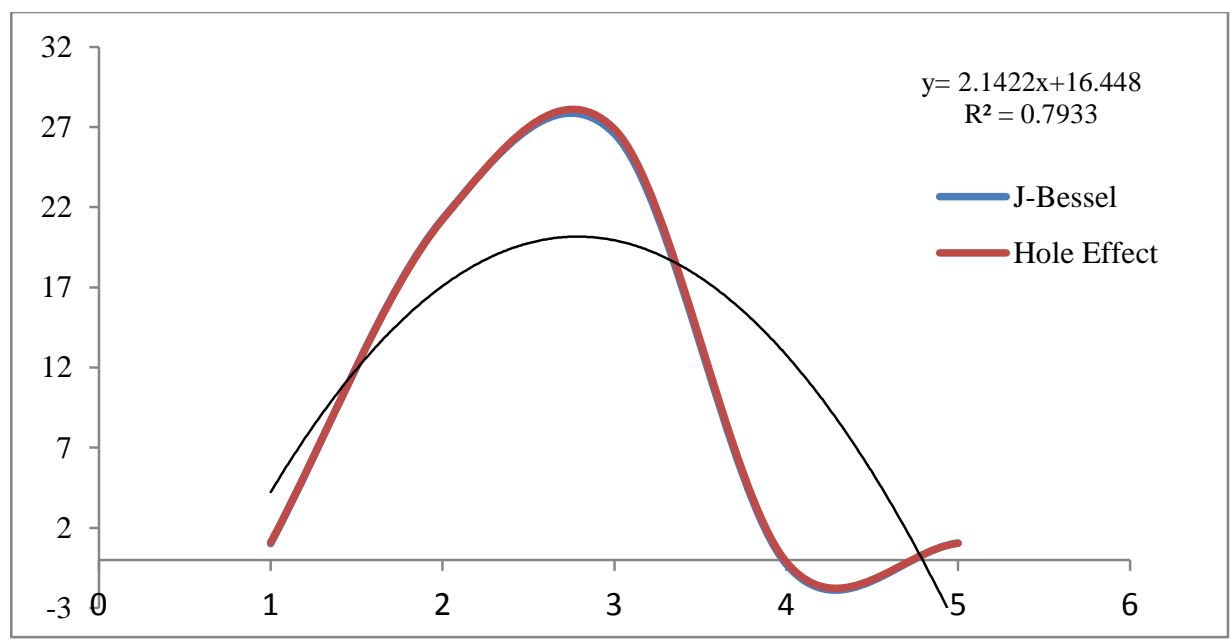

Figure (5): Correlation coefficient between semivariograms models (Hole Effect and J-Bessel).

\section{Conclusions}

According to the modified Storie index rating (O'Geen et al., 2008) method, $4.13 \%$, of the investigated area is good, $30.08 \%$ is fair, $34.92 \%$ is poor for agricultural use and $30.88 \%$ nonagricultural that require special practice for soil conservation. Geostatistical analysis for land capability rates were calculated using variance structure that was performed using eight semivariogram models (Circular, Pentaspherical, Exponential, Gaussian, Rational Quadratic, Hole Effect, K-Bessel and JBessel). These models were evaluated by five prediction errors i.e. mean prediction errors (MPE), root mean square prediction errors (RMSPE), average standard error (ASE), mean standardized prediction errors (MSPE) and root mean square standardized prediction errors (RMSSPE). The results showed that Hole Effect and J-Bessel semivariogram models were the best used models. A positive correlation $\left(\mathrm{r}^{2}=0.7933\right)$ was recorded between the Hole Effect and JBessel semivariogram models.

\section{References}

Abuzaid, A. S. and Fadl, M. E. (2016), "Land evaluation of eastern Suez Canal, Egypt using remote sensing and GIS", Egyptian Journal of Soil Science, Vol. 56 No. 3, pp. 537-547.

Abuzaid, A. S. and Fadl, M. E. (2018), "Mapping potential risks of longterm wastewater irrigation in alluvial soils", Arabian Journal of Geosciences, Vol. 11, pp. 433.

Aldbaa, A. A. (2012), Potential Land Use in the New Reclamation Areas at Wadi El-Rayan Depression and its Environs, EL-Fayum Governorate, Egypt, Ph.D. Thesis, Department of Soil Science, Faculty of Agriculture, Cairo University, 
Cairo, Egypt.

Alvarenga, P., Palma, P., De Varennes, A. and Cunha-Queda, A. C. (2012), "A contribution towards the risk assessment of soils from the São Domingos Mine (Portugal): chemical, microbial and ecotoxicological indicators", Environmental Pollution, Vol. 161, pp 50-56.

Awad, M. Y. M. (2018), "Exploratory Properties and Restrictions of ElZayat Soils for Agricultural Sustainability, El-Dakhla Oasis, Egypt", Journal of Soil Sciences and Agricultural Engineering, Vol. 9 No. 12, pp. 873-879.

Bashour, I. and Sayegh, A. (2007), Methods of Analysis for Soils in Arid and Semi-Arid Regions, FAO, Roma, Italy, pp. 119.

Burrough, P. A. and McDonell, R. A. (1998), Principles of Geographical Information Systems, Oxford University Press, New York, USA, pp. 190.

El-Sayed, M.A. (2016), Land evaluation of Gharb El-Mawhob Area, ElDakhla Oasis, New Valley, Egypt, M.Sc. Thesis, Faculty Agriculture, Assiut University, Assiut, Egypt.

ESRI (2014), Arc Map version 10.2.2, User Manual, 380 New York Street, Redlands, California, 92373-8100, USA.

FAO (1983), Guidelines: Land Ismail, M. Nasr, Y. A. and Kotb, Y.
Evaluation for Rainfed Agriculture, Food and Agriculture Organization of the United Nations, Rome, Italy.

FAO (2006), Guidelines for soil description, $4^{\text {th }}$ edition, Food and Agriculture Organization of the United Nations, Rome, Italy.

FAO, ITPS (2015), Status of the World's Soil Resources (SWSR)-technical summary, Food and Agriculture Organization of the United Nations and Intergovernmental Technical Panel on Soils, Rome, Italy.

Faragallah, M. A. (2001), Some studies on the soils of wadi El-Nuqra, Kom Ombo, Aswan, Egypt, Ph.D. Thesis, Faculty of Agriculture, Assiut University, Egypt.

Gavlak, R., Horneck, D. and Miller, R. O. (2005), Soil, plant and water reference methods for the western region, $3^{\text {rd }}$ Edition, WREP 125, Oregon, USA.

Goovaerts, P. (1997), Geostatistics for Natural Resources Evaluation, Oxford University Press, New York, USA.

Goovaerts, P. (1999), "Geostatistics in soil science: state-of-the-art and perspectives", Geoderma, Vol. 89 No. 1-2, pp. 1-45.

Hesse, P. R. (1998), A Textbook of soil chemical analysis, CBS Publishers and Distributors, Delhi, India. 
(2010), "Assessment of Soils of Wadi El- Natrun Area, Egypt Using Remote Sensing and GIS Techniques", Journal of American Science, Vol. 6 No. 10, pp. 195-206.

ITT (2017), ITT Corporation ENVI 5.1 software, 1133 Westchester Avenue, White Plains, NY 10604, USA.

Nelson, R. E. (1982), Carbonates and gypsum. In: Methods of Soil Analysis Part 2 Chemical and Microbiological Properties, Page, A. L. et al. (Eds), American Society of Agronomy, Soil Science Society of America, Madison, Wisconsin, USA, pp. 181-198.

O'Geen, A. T., Pettygrove, G. S. and Southard, R. J. (2008), A Revised Storie Index for Use with Digital Soils Information, University of California, Division of culture and Natural Resources, USA.

Richards, L.A. (1954), Diagnosis and Improvement of Saline and alkali Soils, United States Salinity Laboratory Staff, Department of Agriculture, Hand Book, No. 60, California, USA.

Rossiter, D. G. (2001), A Practical Framework for Land Evaluation, Unpublished, Enschede, Netherlands.
Sayed, Y. A., El-Desoky, M. A., Gameh, M. A. and Faragallah, M. A. (2016), "Land capability of some soils representing western limestone plateau at Assiut", Assiut Journal of Agricultural Sciences, Vol. 47 No. 3, pp. 120-135.

Schoenberger, P. J., Wysocki, D. A. and Benham, E. C. (2012), Field Book for Describing and Sampling Soils, Version 3.0. Natural Resources Conservation Service, National Soil Survey Center, Lincoln, Nebraska, USA.

Singh, Y. Singh, G. Singh, B. and Cerda, A. (2017), Restoration of degraded salt affected lands to productive forest ecosystem, Geophysical Research Abstracts, Proceedings of $19^{\text {th }}$ EGU General Assembly, Vienna, Austria, pp. 1473.

Sys, C., Van Ranst, E., Debaverye, J. and Beernaert, F. (1991), Land Evaluation, Part I. Principles in Land Evaluation and Crop Production Calculations, Agricultural Publications No. 7, General Administration for Development Cooperation, Brussels, Belgium. 